\title{
Ecological and economic aspects of creating a global environmental management system
}

\author{
Val. V. Matveev ${ }^{1}, V l . V$. Matveev $^{1}$, and A.V. Serbulov ${ }^{2}$ \\ ${ }^{1}$ LLC NPP "Energy Logistics", Kaliningrad, Russia \\ ${ }^{2}$ Immanuel Kant Baltic Federal University, Kaliningrad, Russia
}

\begin{abstract}
The authors argue that a market monetary approach to environmental management is not effective. In this regard, the article proposes theoretical background and practical recommendations for creating a global ecology management system based on the operational assessment of the current environmental impact magnitude. This system allows calculating the environmental value of products, as well as a number of key indicators of environmental performance, which are direct analogues of economic performance indicators. The proposed economic approach, based on the use of accounting methods, provides an opportunity to establish a mathematically accurate correlation between the economic and environmental results of economic and other related activities. The application of carbon emission data for selecting the "cleanest" type of generator that provides the least amount of total globally significant $\mathrm{CO}_{2}$ emissions has been analyzed as an example.
\end{abstract}

\section{Introduction}

The United Nations Framework Convention on Climate Change (UNFCCC) has united humankind in the transition from environmental protection to environmental management. This is evidenced by the goal and the means to achieve it. Over the millennia, mankind has intensified the anthropogenic impact on nature and has now come to the point where the understanding of responsibility for the ecosystem should finally be realized in concrete programme actions for its conservation. Attempts of previous scientific research to understand the mechanisms and possible boundaries of assimilation and management of the natural human habitat have brought the awareness that ecology is becoming more and more similar to the economy, with the only difference that it expands the boundaries of management to global and increases the number of actors involved in a single management process, up to all mankind.

This circumstance defines the goal of the current research as to assess the possibility of transferring the experience of scientific management in the development of the economy to the environment in terms of the anthropogenic impact and natural assimilation processes. As you know, a giant step in the development of the economy was provided by the development of accounting functions of management activities, namely, accounting and management accounting. The concepts of cost, economic efficiency, economic performance, profit, loss and others have become very important elements of its development. 
The concept of "environmental cost" adopted in the economy [3,4,5,9,10,15] implies a margin arising as a result of the need for economic investments to neutralize the direct, indirect environmental consequences of this form of economic activity (cleaning, establishing reserve zones, damage, etc. other factors). The economy does not mathematically link the value of this mark-up, measured in monetary units, with the value of neutralizing the consequences of this form of economic activity in natural units of measurement due to the use of funds received in the form of a mark-up. Therefore, the efficiency of investments received in the form of an environmental margin is calculated by economic parameters.

The lack of a description of the mathematical relationship between the environmental margin and balancing the consequences of economic activity creates the conditions under which investments are directed to projects that are economically productive though with uncertain environmental efficiency. The environmental cost, which is determined according to Russian and international standards [11-14], is meant for production systems. The methodology for determining the costof the ecological efficiency of production systems set out in the standards is based on special studies of their life cycles based on statistical information. It is project-specific and is not intended to continuously provide individuals, households and business communities with complete, objective and reliable information about the environmental impact of their daily activities. Therefore, the standard methodology cannot be used as a basis for the development and implementation of environmentally effective everyday decisions about consumption, lifestyle and investment [2].

The standard methodology for calculating environmental performance in terms of environmental impacts provides that only general recommendations and forecasts are developed, which do not directly refer to the current situation. The lack of such a link is also characteristic of the "market" approach to environmental management, which is applied by the UNFCCC through the global allocation and trade of greenhouse gas emissions quotas $[6,8]$.

In our opinion, in order to develop and implement environmentally effective everyday solutions, a global ecology management system should be set up, based on the operational accounting of the values of current environmental impacts, the calculation of the values of the ecological cost of products, production systems, services, their environmental efficiency, as well as the time when the negative consequences of economic activity are mitigated, etc. [16].

It is well known that the accounting of income and costs in any activity guarantees the completeness, objectivity and reliability of information on the value of any product and service in monetary terms. Attempts to use other units of measurement, for example, labor (workdays), have failed. Therefore, the use of a "market" approach to environmental management through monetary units will not succeed.

Consequently, the same as with the economy, the current environmental management should be based on the current assessment of the environmentalimpact magnitude. It will further calculate the current environmental costs of products, production systems, services and any other activity, as well as their environmental efficiency, the duration and volumes of recovery of environmental damage from economic activities, and other parameters. They will define environmentally effective management decisions and investment priority of economic and social projects.

Contrary to the existing method of institutional economic compensation for depersonalized environmental damage, the proposed adopted economic methods for environmental management makes it possible to personify the responsibility of all "contactees" and, first of all, business entities for their specific impact on the environment. 


\section{Materials and methodology}

\subsection{Current accounting of environmental impacts}

The accounting methodology, which is proposed to be borrowed from accounting, has been used in the economy for more than 500 years. It assumes that many different economic and financial transactions when reflected in the accounting form (balance sheet) are reduced to two interrelated categories: debit (income) and credit (expense). By analogy, it is proposed to divide any anthropogenic impact on the environment associated with the economic activities of organizations into two categories for accounting purposes: "recovery" and "damage".

Recovery is taking into account the results of activities aimed at positively changing the values of parameters that characterize the state of the environment.

Damage is an accounting of the results of activities that are not included in the category of recovery and are referred to below as business activities.

The environmental accounting determines the composition of "recovery" and "damage", the list of parameters, their measurement units, methods for their calculation, the development of standards, the set-up of technical means of measurement and control, personnel training, etc.

The proposed accounting system will make it possible to borrow from the economy analysis, planning, calculation of the ecological cost of the economic activity, its ecological efficiency, methodology of managing the current balance between recovery and damage. It will also make it possible to redeem damage to the environment throughout the entire life cycle of products, services and other economic results, similar to redeeming a certain type of resource in the economy.

The first step in the set-up of an accounting system for environmental impacts is $\mathrm{CO}_{2}$ accounting. Its purpose is to keep $\mathrm{CO}_{2}$ accounting as part of a global environmental accounting, similar to economic accounting, and thereby create the prerequisites for global environmental governance.

$\mathrm{CO}_{2}$ accounting is supposed to be carried out in a standard way and, therefore, it can be used when creating similar accounting systems for other types of impacts. It will avoid or reduce the use of technologies, solutions, actions and investments that are advertised as "low carbon", "carbon free" and even "clean" due to low local $\mathrm{CO}_{2}$ emissions, although in reality they increase globally significant carbon emissions and other harmful effects. Globally significant emissions refer to $\mathrm{CO}_{2}$ emissions over the entire life cycle of the product in question, not just local emissions at the site and at the very moment when it is used. For example, studies carried out two years ago by experts from the Munich Institute for Economic Research (CESifo) [1] showed that the total $\mathrm{CO}_{2}$ emission during the life cycle of a Tesla Model 3 electric car was 159 grams per $1 \mathrm{~km}$ of track, and $\mathrm{CO}_{2}$ emissions from a Mercedes C 220d with a diesel engine - only 117 grams! But these studies did not take into account the emissions of nitrogen oxides, hydrocarbons and other globally significant harmful impacts of the compared vehicles.

Strategically, the development and implementation of a digital accounting system, first of carbon emissions, and then of other types of emissions, will make it possible to quickly obtain more complete information about all goods and services everywhere without carrying out special studies of their life cycles. Accurate and scientifically accepted analysis of the maximum number of all types of impacts will allow using the standard methods described in [11-14] to calculate a generalized criterion for the emissions impact on the environment. Complete, scientifically reliable and unbiased information obtained with the generalized criterion will be the background for global environmental management by keeping the balance between recovery and environmental damage. 
Similar to the standardized methodological techniques for accounting for consumption (credit), adopted in accounting, $\mathrm{CO}_{2}$ emissions can be reflected in the right side of the document on environmental accounting under the general title "Damage". Accordingly, all restorative effects, for example, the amount of $\mathrm{CO}_{2}$ removed from the environment or generalized restorative effect can be seen in its left part under the general title "Recovery".

The general strategy of the current environmental impact accounting includes collecting and sharing with individuals, households and economic communities (enterprises, companies, etc.) complete, impartial and scientifically reliable operational information on the impacts associated with the production of goods, services and any other activity that involves an impact on environment [7]. The lack of such information provided for users results in ineffective and erroneous decisions, actions and investments on a local and global scale.

The modern energy paradigm provides for a widespread and unconditional transition to the so-called decarbonization technologies because there is practically no $\mathrm{CO}_{2}$ emission in the place of their use. However, this decision did not consider the cumulative emissions arising at all stages of the life cycle of equipment for "carbon-free" technologies, that is, during its manufacture, delivery, installation, adjustment, maintenance, repair, disposal, etc. In addition, the "toxicity" of technologies and materials used in the construction of buildings and structures, in the production of building materials, in the supply of fuel and energy resources, etc. was not taken into account either. It is quite obvious that these "destroyers" of ecological balance can be extensive and are directly related to the energy transition to "carbon-free" technologies!

At the same time, it would not occur to anyone to start any environmentally friendly project without a preliminary economic feasibility study based on the financial section of the business plan and analysis of the financial statements of the investor and the customer.

It is obvious that any project, which in the future may turn out to be environmentally charged, will first require investments for its implementation, and then even more investments to eliminate or mitigate its negative consequences. Moreover, mitigation does not consider carbon emissions arising while restoration is being taken. For example, the planned investment in the above-mentioned energy transition is over $\$ 100$ trillion [2]. Therefore, the cost of a possible error and elimination of its consequences is extremely high. At the same time, the cost of creating a system for accounting for environmental impacts on the environment, proposed in this article, is much less than the planned volume of investments in decarbonization of the economy.

\section{Results and discussion}

\subsection{An example of generating accounting data for $\mathrm{CO}_{2}$ emissions}

Table 1 shows an example how to work out the indicators for accounting environmental damage from several types of electrical energy generators. They are developed to select the "cleanest" generator that provides the least amount of total globally significant $\mathrm{CO}_{2}$ emissions. 
Table 1. Indicators for accounting environmental damage from the use of generators.

\begin{tabular}{|c|c|c|c|c|c|c|c|c|c|}
\hline \multirow[b]{2}{*}{$\mathrm{j}$} & \multirow{2}{*}{$\begin{array}{l}\text { Indicator } \\
\text { name and } \\
\text { source }\end{array}$} & \multirow[b]{2}{*}{ Sign } & \multirow{2}{*}{$\begin{array}{l}\text { Measur } \\
\text { ement } \\
\text { Unit }\end{array}$} & \multicolumn{6}{|c|}{ Generator type (i) and designation } \\
\hline & & & & $1 \mathrm{D}$ & 2 GTE & $\begin{array}{c}3 \\
\text { SGTI }\end{array}$ & 4 HPS & $5 \mathrm{~W}$ & $6 \mathrm{~S}$ \\
\hline & $\begin{array}{l}\text { Local } \\
\text { specific } \mathrm{CO}_{2} \\
\text { emission at } \\
\text { the place of } \\
\text { operation } \\
\text { according to } \\
\text { the passport }\end{array}$ & $\mathrm{E}_{\mathrm{iCO}_{2}}^{\mathrm{V}}$ & $\begin{array}{l}\mathrm{kg} / \\
\mathrm{kWh}\end{array}$ & 0.78 & 0.81 & 0.756 & 0 & 0 & 0 \\
\hline 1 & $\begin{array}{l}\text { Total } \mathrm{CO}_{2} \\
\text { emissions } \\
\text { during } \\
\text { manufacturin } \\
\mathrm{g}\end{array}$ & $\mathrm{Q}_{1 \mathrm{iCO}}^{\mathrm{c}}$ & $\mathrm{t} / \mathrm{pc}$ & 456.9 & 13180 & $\begin{array}{c}12585 \\
00\end{array}$ & $311.6^{*} 10^{6}$ & $\begin{array}{c}101.2 \\
4\end{array}$ & $\begin{array}{c}102.7 \\
0\end{array}$ \\
\hline 2 & $\begin{array}{l}\text { Total } \mathrm{CO}_{2} \\
\text { emissions } \\
\text { during } \\
\text { transportatio } \\
\mathrm{n}\end{array}$ & $\mathrm{Q}_{2 \mathrm{iCO}_{2}}^{\mathrm{c}}$ & $\mathrm{t} / \mathrm{pc}$ & 34.34 & 990.72 & 94569 & $23.42 * 10^{6}$ & 7.61 & 7.72 \\
\hline 3 & $\begin{array}{l}\text { Total } \mathrm{CO}_{2} \\
\text { emission } \\
\text { during } \\
\text { installation } \\
\end{array}$ & $\mathrm{Q}_{3 \mathrm{iCO}}^{\mathrm{c}}$ & $\mathrm{t} / \mathrm{pc}$ & 4.32 & 124.64 & 11898 & $2.946^{*} 10^{6}$ & 0.96 & 0.97 \\
\hline 4 & $\begin{array}{l}\text { Total } \mathrm{CO}_{2} \\
\text { emission } \\
\text { during fixing }\end{array}$ & $\mathrm{Q}_{4 \mathrm{iCO}_{2}}^{\mathrm{c}}$ & $\mathrm{t} / \mathrm{pc}$ & 0.53 & 15.29 & 1459.7 & 361400 & 0.12 & 0.12 \\
\hline 5 & $\begin{array}{l}\text { Total } \mathrm{CO}_{2} \\
\text { emissions } \\
\text { during } \\
\text { operation }\end{array}$ & $\mathrm{Q}_{5 \mathrm{iCO}_{2}}^{\mathrm{c}}$ & $\mathrm{t} / \mathrm{pc}$ & 0.18 & 5.20 & 496.25 & 122880 & 0.04 & 0.04 \\
\hline 6 & $\begin{array}{l}\text { Total } \mathrm{CO}_{2} \\
\text { emissions } \\
\text { during } \\
\text { repairs }\end{array}$ & $\mathrm{Q}_{6 \mathrm{iCO}}^{\mathrm{c}}$ & $\mathrm{t} / \mathrm{pc}$ & 6.1 & 176 & 16800 & $4.16^{*} 10^{6}$ & 1.35 & 1.37 \\
\hline 7 & $\begin{array}{l}\text { Total } \mathrm{CO}_{2} \\
\text { emissions } \\
\text { during supply }\end{array}$ & $\mathrm{Q}_{7 \mathrm{iCO}_{2}}^{\mathrm{c}}$ & $\mathrm{t} / \mathrm{pc}$ & 26.82 & 773.82 & 73860 & $18.29 * 10^{6}$ & 5.94 & 6.03 \\
\hline 8 & $\begin{array}{l}\text { Total } \\
\mathrm{CO}_{2} \text { emission } \\
\text { during } \\
\text { disposal }\end{array}$ & $\mathrm{Q}_{8 \mathrm{iCO}_{2}}^{\mathrm{c}}$ & $\mathrm{t} / \mathrm{pc}$ & 112 & $\begin{array}{c}3231.4 \\
8\end{array}$ & $\begin{array}{c}30846 \\
0\end{array}$ & $76.38^{*} 10^{6}$ & 24.81 & 25.17 \\
\hline & $\begin{array}{l}\text { Passportcapa } \\
\text { city }\end{array}$ & $N_{i}$ & $\mathrm{kw}$ & 120 & 16000 & $\begin{array}{c}80000 \\
0 \\
\end{array}$ & $1.2 * 10^{6}$ & 3 & 3 \\
\hline & $\begin{array}{l}\text { Passportwork } \\
\text { resource }\end{array}$ & $T_{i}$ & years & 10 & 12 & 12 & 50 & 6 & 6 \\
\hline
\end{tabular}

Source: the table is compiled on author's calculations. To cut it short, it is accepted that $\mathrm{CO}_{2}$ emissions are monitored everywhere, therefore the information on all types of emissions is contained in the accompanying documents for each generator and in the standards for all $\mathrm{j}$-types of work in the same way as it is organized when accounting for economic costs.

In the given example, the following types of generators are used: $\mathrm{i}=1$ - diesel driven generator (in the table - D), i = 2 - gas turbine engine generator (GTE), i = 3-steam and gas turbine installation (SGTI); $i=4$ - hydraulic turbine generator (HPS), i $=5$ - wind turbine generator $(\mathrm{W}), \mathrm{i}=6$ - photoconverter of solar energy generator $(\mathrm{S})$.

The algorithm for $\mathrm{CO}_{2}$ emissions data collection through the life cycle of the compared generators of electrical energy can be represented by the following sequence of actions.

A) Making up a list of compared types of i-generators. 
B) Making up a list of j-types of $\mathrm{CO}_{2}$ emissions related to the use of compared generators (production facilities, general economic activities, etc.).

C) Making up a list of k-types of $\mathrm{CO}_{2}$ emissions during the operation of compared generators (the actual operation of the generators, the production of fuel and energy resources for the operation of generators, etc.).

D) Data collection on the quantities of j-types of $\mathrm{CO}_{2}$ emissions into the environment (Qcij) directly related to the use of the compared i-generators.

It is common knowledge that any stage, let's say manufacturing or operation of a generator, is a source of carbon emissions. For example, when mining ore, excavators, tractors and cars are used to produce metal. They release carbon dioxide into the environment. Automateddata collection for calculating this carbon dioxide emission per 1 ton of mined ore does not present technical difficulties in the digital economy.

Carbon emissions occur at every stage of the technological process necessary for the manufacture, delivery, installation, adjustment and bringing the final energy-generating products to operating condition (metallurgy, mechanical engineering, transport, etc.).

The system for accounting for environmental impacts is innovative in identifying among the characteristics of the final product both its cost in monetary terms, and its environmental cost, expressed in the amount of carbon emissions during its production.

To collect this information, any known method that gives a sufficiently accurate result can be used. The best way to collect it is to use a special automatic system equipped with flow sensors and gas analyzers.

E) Collection of information on the specific emission of $\mathrm{CO}_{2}\left(\mathrm{E}_{\mathrm{vi}}\right)$ into the environment from the compared i-generators per unit of their capacity (production) in the process of energy generation.

F) Making up a list of j-types of work associated with the use of generators.

$\mathrm{G})$ Collection of information on the absolute values of $\mathrm{CO}_{2}$ emissions, measured in tons per generator $(\mathrm{t} / \mathrm{pc})$, when performing the $\mathrm{j}$ - jobs associated with the use of each compared i-generator being, $\mathrm{Q}^{\mathrm{c}} \mathrm{jiCO}$.

H) Collection of information on the passport capacity of each i-generator - $W_{i}$, its passport working resource $-\mathrm{T}_{\mathrm{i}}$.

The accounting data generated in Table 1 contain complete and objective information that can be used to select the best type of generator based on the criterion of a minimum negative impact on the environment while meeting demand for electricity.

The best generators in terms of zero local $\mathrm{CO}_{2}$ emissions at the site of operation are highlighted green in Table 1 while the worst one is red. It is by the value of the local specific $\mathrm{CO}_{2}$ emission that the sources of renewable energy are evaluated as "environmentally friendly". This assessment method does not take into account other types of emissions in the entire life cycle of each generator, not only in the place and during its operation, but also in other places both before and after its operation. Table 1 shows 8 of such types of emissions. Obviously, only if all types of emissions throughout the entire life cycle of each generator are taken into account, it provides the objectivity of the choice.

It is the calculation of the value of the total emission for all its types, that gives reason to call the resulting value globally significant. An example of using the proposed accounting below shows the methodology for calculating this value. It uses the method of amortization of specific types of $\mathrm{CO}_{2}$ emissions (that is, attributing their values to the results of all economic activities), which is borrowed from the economy.

\subsection{An example of data evaluation}

In this example under study, it is assumed that the criterion for choosing the best type of generator to meet the community's annual energy demand with a volume of $\mathrm{N}_{\mathrm{n}}$ is the 
minimum of the total globally significant $\mathrm{CO}_{2}$ emissions for the year of operation. The calculation of the values of globally significant $\mathrm{CO}_{2}$ emissions for each of the compared generators is carried out on the basis of the accounting data from Table 1, in the following order:

I) Calculation of the total absolute amounts of $\mathrm{CO}_{2}$ emissions for each i-generator when all $\mathrm{j}$-jobs are performed during the entire life cycle according to the formula:

$$
Q_{i \mathrm{CO}_{2}}^{c}=Q_{1 \mathrm{iCO}}^{c}+Q_{2 \mathrm{iCO}}^{c}+Q_{3 \mathrm{iCO}_{2}}^{c}+Q_{4 \mathrm{iCO}_{2}}^{c}+Q_{5 \mathrm{iCO}_{2}}^{c}+Q_{6 \mathrm{iCO}_{2}}^{c}+Q_{7 \mathrm{iCO}_{2}}^{c}+Q_{8 \mathrm{iCO}_{2}}^{c}, \mathrm{t} / \mathrm{pc},(1)
$$

The results of calculations performed for all generators according to formula (1), and subsequent calculations are recorded in Table 2.

J) Calculation of the number of generators of the i-type, sufficient to meet the annual needs of the community in electricity by the formula:

$$
\mathrm{N}_{\mathrm{Gi}}=\mathrm{N}_{\mathrm{n}} / N_{\text {ipc }}, \mathrm{pc}
$$

K) Calculation of the total amounts of $\mathrm{CO}_{2}$ emissions when all the j-jobs are performed, attributable to the results of the annual use of each i-type of generator (depreciation of the value $Q_{i \mathrm{CO}_{2}}^{\mathrm{c}}$ by assigning it to each year of operation), according to the formula:

$$
\mathrm{Q}_{n i \mathrm{CO}_{2}}^{\mathrm{c}}=\mathrm{Q}_{i \mathrm{CO}_{2}}^{\mathrm{c}} * \mathrm{~N}_{\mathrm{Gi}} / T_{i}, \mathrm{t} / \text { year, }
$$

L) Calculation of the total amounts of local $\mathrm{CO}_{2}$ emissions with annual use of each i-type of generator according to the formula:

$$
\mathrm{Q}_{n i \mathrm{CO}_{2}}^{\mathrm{v}}=24 * 365 * \mathrm{E}_{\mathrm{iCO}_{2}}^{\mathrm{v}} * \mathrm{~N}_{\mathrm{n}} / 1000, \mathrm{t} / \text { year, }
$$

M) Calculation of the total globally significant amount of carbon emissions with the annual use of each i-type of generator according to the formula:

$$
\mathrm{Q}_{\mathrm{niCO}_{2}}^{\mathrm{t}}=\mathrm{Q}_{\mathrm{niCO}_{2}}^{\mathrm{c}}+\mathrm{Q}_{\mathrm{niCO}_{2}}^{\mathrm{v}}, \mathrm{t} / \text { year, }
$$

N) Calculation of the increase in damage from a possible erroneous decision when choosing the type of generator.

The increase in damage from a possible erroneous decision when choosing a generator type is calculated as the difference between each amount of the total globally significant $\mathrm{CO}_{2}$ emissions and the smallest of them using the formula:

$$
\Delta Q_{\text {niCO }_{2}}^{\mathrm{t}}=Q_{\text {niCO }_{2}}^{\mathrm{t}}-\left|Q_{\text {niCO }_{2}}^{\mathrm{t}}\right|_{\min } \mathrm{Tt} / \text { year, }
$$

In formula (6), the symbol $\left|Q_{\text {nico }}^{t}\right|_{\text {min }}$ corresponds to the minimum amount of $Q_{\text {nico }_{2}}^{t}$ of all its values in Table 2. 
Table 2. Calculation of indicators of the total value of globally significant $\mathrm{CO}_{2}$ emissions for selecting the most preferable (environmentally friendly) energy generator

\begin{tabular}{|c|c|c|c|c|c|c|c|c|}
\hline \multirow{2}{*}{ Title } & \multirow{2}{*}{$\begin{array}{l}\text { For } \\
\text { mula }\end{array}$} & \multirow{2}{*}{$\begin{array}{l}\text { Measu } \\
\text { re }\end{array}$} & \multicolumn{6}{|c|}{ Generator type (i) and designation } \\
\hline & & & $1 \mathrm{D}$ & 2 GTE & 3 SGTI & $4 \mathrm{HPS}$ & $5 \mathrm{~W}$ & $6 \mathrm{~S}$ \\
\hline $\begin{array}{l}\text { The amount of } \\
\text { local } \mathrm{CO}_{2} \\
\text { emissions from } \\
\text { the i-generator } \\
\text { per year when } \\
\text { performing the j- } \\
\text { jobs }\end{array}$ & $\mathrm{Q}_{\mathrm{CCO}_{2}}^{\mathrm{c}}$ & t/year & 641.2 & 18500 & $\underset{6}{1.766 * 10}$ & $\underset{6}{437.3} * 10$ & 142.07 & 144.12 \\
\hline $\begin{array}{l}\text { Number } \\
\text { ofgenerators }\end{array}$ & $\mathrm{N}_{\mathrm{Gi}}$ & $\mathrm{pc}$ & 6667 & 50 & 1 & 1 & $\begin{array}{c}26666 \\
7\end{array}$ & $\begin{array}{c}26666 \\
7\end{array}$ \\
\hline $\begin{array}{l}\text { The total amount } \\
\text { of } \mathrm{CO}_{2} \text { emissions } \\
\text { from all i- } \\
\text { generators per } \\
\text { year when } \\
\text { performing the j- } \\
\text { jobs }\end{array}$ & $\mathrm{Q}_{\mathrm{inCO}_{2}}^{\mathrm{c}}$ & t/year & $\underset{6}{0.427} * 10$ & $\begin{array}{c}0.077^{*} \\
10^{6}\end{array}$ & $\underset{6}{0.147} * 10$ & $5.83 * 10^{6}$ & $\begin{array}{c}6.315^{*} \\
10^{6}\end{array}$ & $\begin{array}{c}6.405^{*} \\
10^{6}\end{array}$ \\
\hline $\begin{array}{l}\text { The amount of } \\
\text { local } \mathrm{CO}_{2} \\
\text { emissions from } \\
\text { all i-generators } \\
\text { per year }\end{array}$ & $\mathrm{Q}_{\mathrm{inCO}_{2}}^{\mathrm{V}}$ & t/year & $5.47 * 10^{6}$ & $\begin{array}{c}5.68 * 1 \\
0^{6}\end{array}$ & $5.3^{*} 10^{6}$ & 0 & 0 & 0 \\
\hline $\begin{array}{l}\text { The total amount } \\
\text { of globally } \\
\text { significant } \mathrm{CO}_{2} \\
\text { emissions from } \\
\text { all i-generators } \\
\text { per year }\end{array}$ & $\mathrm{Q}_{\mathrm{inCO}_{2}}^{\mathrm{t}}$ & t/year & $\underset{6}{5.894} * 10$ & $\begin{array}{c}5.754^{*} \\
10^{6}\end{array}$ & $\underset{6}{5.445} * 10$ & $5.83 * 10^{6}$ & $\begin{array}{c}6.314^{*} \\
10^{6}\end{array}$ & $\begin{array}{c}6.405^{*} \\
10^{6}\end{array}$ \\
\hline $\begin{array}{l}\text { Increased damage } \\
\text { from a possible } \\
\text { erroneous } \\
\text { decision }\end{array}$ & $\begin{array}{c}\Delta \\
\mathrm{Q}_{\mathrm{icO}}^{\mathrm{t}}\end{array}$ & t/year & $\underset{6}{0.448} * 10$ & $\begin{array}{c}0.308^{*} \\
10^{6}\end{array}$ & 0 & $\underset{6}{0.385 * 10}$ & $\begin{array}{c}0.869^{*} \\
10^{6}\end{array}$ & $\begin{array}{c}0.96^{*} 1 \\
0^{6}\end{array}$ \\
\hline
\end{tabular}

Source: compiled on the author's calculations

O) Choosing the "cleanest" generator that provides the least amount of total globally significant $\mathrm{CO}_{2}$ emissions.

Comparison of the calculation results in Table 2 shows that the "cleanest" generator in the considered example is a generator driven by a combined cycle gas turbine unit, which has $\left|\mathrm{Q}_{\mathrm{n} 3 \mathrm{CO}_{2}}^{\mathrm{t}}\right|_{\mathrm{min}}=\mathbf{5 . 4 4 5} * \mathbf{1 0}^{6} \mathrm{t} /$ year, and the "dirtiest" one is a generator with a solar energy photoconverter, which has $\left|Q_{n 6 \mathrm{CO}_{2}}^{\mathrm{t}}\right|_{\max }=\mathbf{6 . 4 0 5}^{*} \mathbf{1 0}^{6} \mathrm{t} /$ year. The choice of the best generator with the use of depreciation of certain types of $\mathrm{CO}_{2}$ emissions made it possible to avoid

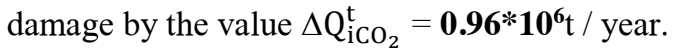

The proposed accounting method is of particular importance when choosing the best project for the energy transition when implementing the UNFCCC framework convention. It is the first to make it possible to choose the best renewable energy source in terms of its total globally significant impact on the environment. For example, table 2 shows that according to this criterion the best of those compared is a generator driven by a water turbine (4 HPS), which has a value of $\mathrm{Q}_{\mathrm{inCO}_{2}}^{\mathrm{t}}=5.83 * 10^{6} \mathrm{t} /$ year.

The calculation results presented in Table 2 refer only to a specific project. In addition, any change at each stage of the product life cycle can significantly change the values of $\mathrm{Q}_{i \mathrm{CO}_{2}}^{\mathrm{C}}$ and, accordingly, the relationship between $\mathrm{E}_{i \mathrm{CO}_{2}}^{\mathrm{t}}$ of different types of generators.

Obviously, the proposed system of environmental impacts accounting can be applied not only for carbon emissions, but also for any toxic substance (mercury, organophosphorus compound, etc.), irritant (acid, alkali, etc.), sensitizing substance (aldehyde, solvent, etc.), a 
carcinogenic substance (asbestos, arsenic, etc.), a mutagenic substance (lead, manganese, etc.), industrial dust of any origin, electric fields, radiation (electromagnetic, acoustic, infrared, etc.), etc.

The economic approach described above, based on the use of accounting methods for environmental impacts, provides an opportunity to establish a mathematically accurate relationship between the economic and environmental results of economic and other activities. For example, purchasing materials, products, equipment or services at a low economic price, but with a high environmental cost, an economic entity assumes the obligation to make up for environmental damage, which is indicated in the environmental cost. The price of recovery per unit of environmental damage can be determined by the market or set by government agencies. Publicauthorities can set quotas for impacts, benefits, fines, tariffs for specific types of impacts for specific categories of economic entities.

\subsection{Environmental Cost}

Previously, we showed the disadvantages of using the economic equivalent of the "environmental cost" concept, measured in monetary units. It is obvious that the environmentalcost of products can be similar to its economic value, but expressed in the amount of damage to the environment per unit of the result of economic activity. The environmental cost of products can be measured in units of mass or volume of harmful substances released into the environment (damage) or removed from it (recovery). Since there can be many types of impacts, to simplify accounting, all their quantities can be recalculated into an equivalent measurement unit according to existing methods, for example, according to standards [11-14].

If we are talking about the current environmental cost of a product, then it should consider the impact on the environment during the life cycle from the moment when the product is created until the current moment of accounting. After the current moment in time, the value of the environmental cost of this product will change under the influence and depending on the intensity of its use by the consumer (owner, tenant). According to the logic described above, it is also possible to determine the environmental value of products at some past or future moment.

Thus, the environmental cost of products, services and any other economic activity is the total impacts

environmental cost is the total amount of damage to the environment from the beginning of the life cycle of the assessed product, service or result of another activity until the moment of its calculation per unit of measurement of this product, service or result of another activity. In other words, the environmental cost characterizes the total environmental impact during the calculated period of the life cycle, taking into account recovery activities, per unit of measurement of the result of this activity or per unit of time of the calculated period of economic activity.

The value of the ecological $\operatorname{cost}\left({ } \mathrm{C}_{\mathrm{u}}\right)$ is proposed to be calculated by the formula:

$$
\exists \mathrm{C}_{\mathrm{u}}=\frac{\sum \mathrm{Q}_{L C}}{\sum \mathrm{Q}_{\mathrm{g}}},
$$

Where: $\sum Q_{L C}$ - the number of harmful effects on the environment of the considered products, services and the results of any other activity for the entire life cycle of the project since their creation (design), from the beginning of the life cycle to the forecast moment, until the current moment (with current management) or until the change of theowner;

$\sum \mathrm{Q}_{\mathrm{g}}$ - the number of products, services or satisfaction of any need, respectively, for the entire life cycle of the project since their creation (design), from the beginning of the 
project life cycle to the forecast moment, from the beginning of the project life cycle to the current moment (at the current management), from the beginning of the project life cycle or until transfer to another owner.

If we compare the process of calculating the environmental costof a product with its economic value, then the environmental costis calculated according to the same methodology.

The current $\Im_{\mathrm{u}}$ value during the implementation of the same project under different operating conditions, different modes of its operation, changes in supply, maintenance, repair and other conditions, can vary within a fairly wide range. The ability to calculate the value of $\mathrm{JC}_{\mathrm{u}}$ at the current time allows you to maintain a minimum of its value by maintaining the appropriate equipmentoperating mode.

\section{Conclusions}

The similarity between theenvironmental processes and economic ones allows borrowing the most important economic categories and methodology for managing the state of the environment. As a result of the application of economic performance indicators based on data from the global carbon accounting system, dramatic reductions in time, material, labor and financial resources are expected to achieve better environmental results due to:

- developing continuous current accounting of the environmental impacts, similar to accounting in the economy;

- rejection of economic units of measurement when defining the concepts of environmental value and efficiency;

- abandoning the "market" method of environmental management through quotas on the magnitude of environmental impacts and trading in quotas;

- rules for setting the priority of financing environmental projects.

In the future, the use of the proposed toolkit will allow for extreme environmental management at any current moment in time.

There are no technical obstacles to implementing the proposed borrowing of economic approaches to environmental management. Its success is predetermined by the global digitalization of management and the accumulated experience of economic management.

\section{References}

1. Buchal, Christoph, Hans-Dieter Karl and Hans-Werner Sinn, Kohlemotoren, Windmotoren und Dieselmotoren: Was zeigt die $\mathrm{CO}_{2}$-Bilanz?72(08)(2019) https://www.greencarcongress.com

2. Christian de Perthuis and Pierre-André Jouvet,Climate Change: The Challenges of Carbon Pricing (Columbia University Press, 2015)

3. Dieter Helm, Natural Capital: Valuing the Planet,296 (Yale University Press,2016)

4. Dieter Helm, Oxford Review of Economic Policy, 24(2),211 (2008)

5. Dieter Helm, The Carbon Crunch: How We're Getting Climate Change Wrong-and How to Fix It Hardcover, 304 (Yale University Press, 2012)

6. IEA, World Energy Outlook 2020 (IEA, Paris, 2020)https://www.iea.org

7. Kirsten Westphal, Oxford Energy Forum,126, 9 (2021)

8. The secretary-general's advisory group on energy and climate change (AGECC). Energy for Sustainable Future. Summary report and recommendations (New York, 2010)http://www.unido.org 
9. P.Bezrukih, P. J. Bezrukih, Economic issues, 92(2014)

10. T. Bondarenko, Collection of scientific articles of the All-Russian scientific conference dedicated to the 30th anniversary of the SNRC RAS and SSU, 213(Sochi RAS research center, 2018)

11. GOST R ISO 14021: 2000 "Environmental labels and declarations. Self-declared environmental certificates (type I environmental labelling)"] (ISO 14021:1999)

12. GOST R ISO 14040: 2010 Environmental Management Life Cycle Assessment. Principles and structure "] (ISO14040)

13. GOST R ISO 14044: 2007 "Environmental Management. Life Cycle Assessment. Requirements and Recommendations "] (ISO14044)

14. GOST R ISO 14050: 2009 Environmental Management. Dictionary"] (ISO14050)

15. N.V. Eltoshkina, Higher school bulletin. Mining journal, 7,27(2016)

16. Val. V. Matveev, Vl. V. Matveev, Energy transition efficiency, https://www.linkedin.com 